\title{
IELTS as a Literacy-Based Proficiency Test
}

\author{
Sugeng Purwanto ${ }^{\mathrm{a}, *}$ \\ ${ }^{a}$ Universitas Stikubank Semarang, Indonesia
}

\begin{abstract}
This is an exploratory case study aimed at investigating whether or not International English Language Testing Systems (IELTS) scores correspond with literacy levels. During the 2011-2012 academic year, 20 first semester students in the English Literature Program in the Faculty of Language and Cultural Studies (Fakultas Bahasa dan Ilmu Budaya) at Universitas Stikubank (UNISBANK) were randomly selected to take the IELTS. Results were matched against predetermined criteria for literacy levels (Hammond, et al. 1992) in order to classify them into the appropriate levels of literacy. Findings indicate that all students (100 percent) were at the performative level of literacy with respect to their overall IELTS scores. Only 25 percent of the students on the speaking subtest and 20 percent of the students on the reading subtest managed to test at the functional level. It is therefore recommended that action research be conducted in Central Java level to upgrade the level of literacy from the performative level up to the informative level. As well, similar research may be conducted with a multi-disciplinary approach employing a correlational study between IELTS band scores with literacy levels.
\end{abstract}

\begin{abstract}
Abstrak
Studi kasus yang bersifat eksploratif ini bertujuan untuk meneliti apakah skor IELTS memiliki kesesuaian dengan tingkat literasi atau kewicaraan. Pada tahun akademik 2011-2012, sebanyak 20 mahasiswa semester pertama, Program Studi Sastra Inggris, pada Fakultas Bahasa dan Ilmu Budaya, Universitas Stikubank (UNISBANK) diambil secara acak dan dites dengan IELTS. Hasil tes dicocokkan dengan kreteria tingkat kewicaraan (Hammond, et al. 1992) yang telah ditentukan sebelumnya untuk menempatkan mahasiswa pada tingkat kewicaraan yang sesuai. Hasil penelitian menunjukkan bahwa semua mahasiswa tersebut berada pada tingkat kewicaraan performatif sesuai dengan skor utuh IELTS. Hanya 25 persen mahasiswa pada sub-tes berbicara dan 20 persen mahasiswa pada sub-tes membaca, berhasil menduduki tingkat kewicaraan fungsional. Oleh karena itu disarankan agar diadakan penelitian tindakan kelas di tingkat Jawa Tengah untuk menaikkan tingkat kewicaraan dari tingkat performatif menjadi tingkat informatif. Di samping itu, penelitian ini hendaknya ditindaklanjuti dengan penelitian korelasional antara skor rentang IELTS dan tingkat kewicaraan menggunakan ancangan multi-disipliner.
\end{abstract}

Key Words: Literacy, Literacy Levels, IETLS, IETLS Band Scores

\section{Introduction}

It is commonly known that students of any English department at any university in Indonesia are supposed to be able, upon completion of their study, to perform considerably well in the four language skills of listening, speaking, reading and writing. These skills should not be thought of as separate entities. Rather, they have to be considered as one unified whole referred to as communicative competence, which consists of discourse competence, linguistic competence, sociocultural competence,

*Corresponding author. Address: Universitas Stikubank (UNIS. BANK) Semarang, Jl. Tri LombaJuang No. 01, Semarang 50241 actional competence, and strategic competence (Celce-Murcia, Dornyei, and Thurrell 1995).

Nowadays, it is misleading to consider that literacy only deals with the ability to read and write, as was previously thought. Today's notion of literacy includes all skills that are required of any individual who wants to survive in this competitive global context (Purwanto 2007). The skills differ from one individual to another based on his or her environment, which includes the skills obtained or required as a result of and in accordance with the type of work and educational background. In other words, one is labeled as being "literate" if he or she is considered capable of particular discursive practices in line with the linguistic, social and professional skills necessary for a given field.

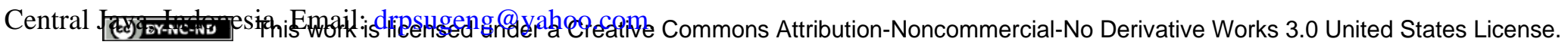
ISSN 2153-9669 (print) 2153-9677 (online) | doi: 10.5195/ehe.2012.63 | http://ehe.pitt.edu 
Given the prevalence and importance of English today coupled with current notions of literacy, the researcher is interested in investigating the correlation between literacy levels and competency standards as outlined in the International English language Testing System (IELTS) test. If a correlation exists, the aim is to use IELTS test results to help determine recommendations for the development of literacy pedagogy at tertiary level in general and at FBIB UNISBANK, English Literature Study Program in particular. Therefore, the study attempts broadly to answer "What average level of literacy do the first year students of FBIB UNISBANK have pursuant to the competency standard as outlined in the IELTS test?” The findings will also reveal the literacy levels for each of the subtests of IELTS, namely listening, reading, speaking, and writing.

\section{Theoretical Framework}

The current study's theoretical framework is literacy education in combination with the IELTS competency standards as, together, they support the development of literacy at the university level with a particular emphasis on the English Literature Study Program.

Literacy used to be conceived as the ability to read and write. The current notion of literacy, however, includes all necessary context-based skills required of an individual who wants to survive in any possible discursive practice in theirvaried communities. The terms functional literacy and critical literacy are used to describe this more recent interpretation of literacy (Holme 2004; Purwanto 2007). The former refers to a literacy as "embodying career-based skills with which an individual can function in a society. An artist, for instance, will have to acquire different literacy from that of a policeperson” (Purwanto 2007, 41). The latter, on the other hand, refers to "self-empowerment of an individual, resulting in several movements, such as gender issues, gay rights, ethnic minority, language rights, to mention only a few, that strongly stand against the global spread of a single modern culture” (Purwanto 2007, 45).

The emergence of critical literacy has inspired a different model of curriculum design termed "competency based curriculum" also referred to as "literacy based curriculum." It can be applied to any school subject and has the single aim of providing students with critical life skills. A student, upon attainment of critical life skills (e.g., interpersonal skills, entrepreneurial skills, and problem solving skills) is presumably able to manage social and professional environments better. A literacy or competency based curriculum as such is well suited for entrepreneurial educational institutions such as the Stikubank University of Semarang whose primary mission is to be a world class entrepreneurial university by 2020. As a result, the Faculty of Language and Cultural Studies (FBIB) in 2011 implemented a competency based curriculum with life skills integrated within it as a pilot project. Other faculties are still in the process of developing competency based curricula.

\section{Literacy Levels}

Similar to other types of education, literacy education is also stratified in terms of levels (Grant 1986; Wells 1987; Freebody and Luke 1990) as outlined below:

- Performative. This level of literacy has become a myth in that it is limited to reading and writing skills. As expressed by Freebody and Luke (1990), it is a level of literacy limited to phonologizing written symbols and writing the symbol. In other words, it deals with accuracy in spelling and pronunciation and being able to physically respond to simple instructions in a particular language. This level of literacy is only matched with entry level jobs.

- Functional. Communication is introduced in this level of literacy, which means that learners are supposed to be able to function at a higher levelthan at the performative level but are limited to physically responding to simple instructions in a particular society (Wells 1987). An individual who has achieved the functional level of literacy can respond to job announcements in a newspaper by writing application letters, for example. He or she can also understand signs such as "No Smoking" including its various symbols. With clear instructions, an individual at this literacy level can perform administrative work and simple calculations.

- Informative. The indicator for the informative level of literacy is that an individual can access particular information from particular media in accordance with his or her discipline (Freebody and Luke 1990). Concretely, at this level an individual can relate the content of a text to his or her background knowledge. In other words, when confronted with a text, he or she understands the main idea and supporting details and can answer questions related to a text. In this respect, an individual may get promoted to a managerial level in line with his or her work experience.

- Epistemic. At this level, not only can an individual access information from the media but he or she can also express it in both oral and written modes. This can be seen in an individual who can write a scientific text such as a term paper, thesis or dissertation. He or she can also make a public speech on a particular discipline. The epistemic level 
of literacy can also be related to a particular level of language proficiency. In this respect, it is in line with an advanced level of language proficiency. It is argued (Purwanto 2007) that this level of literacy is similar to critical literacy. Hammond et al. (1992) further argue that:

[Epistemic literacy] involves more than engaging with written texts; it involves the ability to reflect critically on texts within their socio-cultural contexts in terms of appropriateness and adequacy of content, in terms of the writer's attitude toward this content and where his attitude positions the reader . . . also involves the ability to evaluate how well the text has been constructed, that is its effectiveness as a grafted object. (11)

A discussion on literacy cannot be separated from Diana Brydon's (2010) article “Critical Literacies for Globalizing Times" in which she expresses the necessity for synergizing globalization, global English and literacy, which is in line with concluding remarks at the UNESCO 2009 World Conference on Higher Education. Brydon further argues that English has become a dominant language across the globe and in multidisciplinary perspectives in accordance with the new definition of literacy in pluralistic disciplines.

\section{International English Language Testing System}

IELTS is an internationally-recognized test of English language skills "designed for students who want to study in the medium of English either at university, college or high school” (Jakeman and Mcdowell 2002, 4). Accordingly, it tests competency in the four language skills of listening, speaking, reading and writing. Each skill is scored on a band range of 1 to 9 with 9 being the highest and 1 the lowest. Test takers receive a score for each skill in addition to an overall band score that also follows the 9-band system. Institutions determine their own level(s), which are typically in accordance with their standards. Admission for international students to the MA in Applied Linguistics at Griffith University in Australia, for example, requires an IELTS overall band score of 6.5 with a minimum score of 6.0 for each subtest (Griffith University 2012).

In terms of test administration, there are two types of IELTS: one administered internationally by IELTS test centers and the other administered by any institution preparing candidates for the international IELTS. In other words, IELTS administered outside IELTS test centers is considered "institutional" in terms of both the place of administration and the test papers.

\section{IELTS' Score Band in Relation to Levels of Literacy}

Despite the fact that there has been no agreement between the IELTS score band and levels of literacy, it is possible to link them. As previously mentioned with respect to Griffith University, the score band for its admission requirements is 6.5 with a minimum score of 6.0 for each subtest. Meanwhile in the 2004 competency based curriculum (Kurikulum Berbasis Kompetensi) and the 2006 school based curriculum (Kurikulum Tingkat Satuan Pendidikan), Indonesian high school students aretrained to achieve the informative level of literacy (Department of National Education 2006). Thus, it can be assumed that an IELTS overall bandrange of 6.0-6.5 is equal to an informative level of literacy. In other words, upon completion of their high school program-with respect to English — students are supposed to be at the informative level of literacy. If they take IELTS, their overall band scores should generally range between 6.0-6.5; and they can be admitted to overseas universities that require a specific overall band score that typically falls within this range. In this study, therefore, IELTS' score band range of 6.0-6.5 is matched with the informative literacy level. The functional and performative levels of literacy are matched with IELTS overall score ranges of 5.0-5.5 and 4.0-4.5 respectively. Table 1 shows the relationship between the IELTS score ban ranges and levels of literacy, which can be used to determine a student's level of literacy relative to their IELTS score.

Table 1. IELTS Band Scores in Relation to Literacy Levels

\begin{tabular}{c|c}
\hline IELTS Score Band Range & Literacy Level \\
\hline $6.0-6.5$ & Informative \\
\hline $5.0-5.5$ & Functional \\
\hline $4.0-4.5$ & Performative \\
\hline
\end{tabular}

Source: Created by Author.

\section{Method}

The study is a descriptive qualitative research supported by simple quantification in terms of percentage to indicate the occurrence of a particular phenomenon. Out of 31 undergraduate students in their first semester of the 2007-2008 academic year at FBIB UNISBANK, 20 were randomly selected to participate in the study. All participants were majoring in English Literature. They were requested to take an IELTS test administered and rated by the Language Training Center at UNISBANK, and hence it was institutional in nature.

UNISBANK, the institution from which participants were selected, is known as a moderate university that needs further development in terms of facilities and more proficient lecturers. This 
university admits students from mostly marginalized high schools or those whose applications to state or high ranking universities have been declined. In essence, UNISBANK's admission test is a formality since everyone is granted admission. As a result, the graduates of the few top ranking schools are not likely to apply to and attend UNISBANK. Instead, they prefer to study abroad or at least in higher ranking universities such as Universitas Gadjah Mada and Institute Teknologi Bandung that are accredited by the National Board of Accreditation.

The instrument employed in the study was "Sample Test 1" taken from Jakeman and Mcdowell's 2002 IELTS Practice Test Plus (30-51). There are other IELTS tests designed for institutional contexts with relatively similar levels of difficulty and scoring systems. Although the Sample Test 1 might not have the same validity as the formal IELTS, it was selected for monetary reasons. No modifications were made. The IELTS Sample Test 1 was administered on Saturday, 24 September 2011, when the students had no formal classes. The listening test was conducted in the FBIB Language Laboratory, while the reading and writing tests were conducted in the Hall of UNISBANK. The speaking test was conducted in the Lecturer's Room with FBIB lecturers, all of whom are non-native English speakers with MA degrees in English language pedagogy.

The test papers, including the speaking test were rated on a scale of 1-9; the test results were the data. For ease of reference, the data (i.e., test scores) were then tabulated into a list of participants and their scores. Each score was then matched with the applicable IELTS score band range from Table 1 so participants could be classified into appropriate levels of literacy in accordance with their test results. For example, if Student $\mathrm{X}$ received a listening score of 4 , he or she would be placed at the perfomative level of literacy with respect to his or her listening skill. This procedure was used to classify participants overall score and individual subtest scores into appropriate levels of literacy.

To triangulate the findings, English teachers from top and low ranking schools were interviewed to provide their professional opinion on the IELTS scores in the study. On one occasion, two English teachers, one from Karangturi Senior High School and the other from Loyola Senior High School, were interviewed. These two schools are accredited by Badan Akreditasi Sekolah Semarang as top ranking schools due to their complete facilities and more qualified teachers, all of whom have four-year degrees and national teacher certification and some who have an additional online TESOL certification from Cambridge International Examination Syndicate. On another occasion, two additional English teachers, one from Al Fatah Senior High School who represented the low ranking schools in terms of facilities and teacher qualifications and the other from State Senior High School 15 who represented the moderate ranking schools in terms of facilities and teacher qualifications, were also interviewed. The two pairs of teachers provided feedback on the same tests. The purpose of this triangulation was to learn whether the IELTS scores in the study also represented the general competencies of their students. It is important to note that the study's participants (i.e., those who took the IELTS) were not the teachers' students. The teachers commented on the IELTS scores with reference to their own students.

\section{Findings}

Findings from this study show that most of the scores are unsatisfactory, as shown in Table 2. Most students are at the performative level of literacy in terms of the overall IELTS score. With respect to the subtest scores measuring listening, speaking, reading and writing proficiency, results are varied. All students in subtest 1 , which evaluates listening, are at the performative level of literacy. Results for subtest 2, which evaluates speaking, indicate that only 25 percent of the students managed to achieve a functional level of literacy. Meanwhile, for subtest 3 only 20 percent of the students managed to achieve a functional level of literacy in reading. Finally, results for subtest 4 for writing indicate that all students demonstrated a performative level of literacy.

Table 2. Correlation between Participants' IELTS Scores and Levels of Literacy

\begin{tabular}{l|c|c|c|c|c}
\hline \multirow{2}{*}{$\begin{array}{l}\text { Level of } \\
\text { Literacy }\end{array}$} & \multicolumn{5}{|c}{ IELTS Score (\%) } \\
\cline { 2 - 6 } & $\begin{array}{c}\text { Subtest 1 } \\
\text { listening }\end{array}$ & $\begin{array}{c}\text { Subtest 2 } \\
\text { speaking }\end{array}$ & $\begin{array}{c}\text { Subtest 3 } \\
\text { reading }\end{array}$ & $\begin{array}{c}\text { Subtest 4 } \\
\text { writing }\end{array}$ & Overall \\
\hline Performative & 100 & 75 & 80 & 100 & 100 \\
\hline Functional & 0 & 25 & 20 & 0 & 0 \\
\hline Informative & 0 & 0 & 0 & 0 & 0 \\
\hline Total & 100 & 100 & 100 & 100 & 100 \\
\hline
\end{tabular}

\section{Discussion}

The discussion is centered around the profiles of the secondary schools from which the participants graduated. The schools located in Semarang Municipality are classified into three major groups of schools, namely (1) top-ranking schools, (2) moderate-ranking schools, and (3) low-ranking schools.

The top-ranking schools are self-funded and characterized with the availability of modern language laboratories, unlimited access to cyber technology, updated teaching materials both from local and world class publishers, and, most significantly, well-trained teachers. The moderate-ranking schools, on the other hand, are state-funded with sufficient access to modern technology, locally published teaching materials, and government-employed teachers. Meanwhile, the low-ranking schools, mostly located in the rural 
areas, consist of those with limited access to modern technology, teaching materials and professional teachers.

When the English teachers from the two top-ranking schoolsKarangturi Senior High School and Loyola Senior High Schoolwere interviewed, they said it was possible that the third year students were able to achieve an IELTS band score of 6.5 since the IELTS materials had been integrated into English classes in addition to the national curriculum. In other words, the students could be assumed to have achieved the informative level of literacy. Some of the students had continued to pursue their education overseas and others were admitted to higher ranking universities in Indonesia. When further asked with respect to the national examination, they said that most of the students managed to pass it with ease.

The situation was reverse for the English teachers from $\mathrm{Al} \mathrm{Fa-}$ tah Senior High School, a low-ranking school, and State Senior High School 15, a moderate ranking school. They said that English was a difficult subject for teachers to teach and for students a difficult subject to learn. The teachers who were interviewed identified two possible factors tied to motivation that could influence the success of learning English. Most of the students were motivated to learn English not because they want to use the language, but because they have to pass the national examination. In general, they have no plan of pursuing education abroad. The other factor is that state policy identifies English as a foreign language in Indonesia so people are not required to use English as a lingua franca. Bahasa, the Indonesian language, is the formal and national language.

When shown the IELTS scores of the participants, they commented that they are normal and would not expect much else from the students. They commented that even most university graduates who want to study abroad still have to undertake special training in IELTS or the Test of English as a Foreign Language for at least six months to obtain the minimum standard score for admission to overseas universities.

Despite the fact that the study's participants graduated from less demanding academic programs, this study used a rigorous test instrument that was designed to prepare students for the actual IELTS test. If a test with a moderate level of difficulty had been employed, the results might have been different. The students might have scored higher; but then would not have represented the actual competence required for international student admission. On top of that, the study can indicate the barometer of success in the teaching of English as a foreign language with respect to the marginalized high school students on the basis of which concrete actions toward improvement have to be done accordingly, especially in higher education.

\section{Conclusion and Recommendations}

This was an exploratory case study aimed at investigating whether or not IELTS scores correspond with levels of literacy. First year students majoring in English literature at FBIB UNISBANK who participated in this study were within the performative level of literacy with reference to their overall IELTS score. With respect to the four language skills, 25 percent of the students stayed within the functional level of literacy in speaking, and 20 percent of them managed to stay within the functional level of literacy in reading. Their competency in the other two skillslistening and writing-corresponds to the performative level of literacy.

The current study supports the results of a similar study in the use of IELTS as a barometer of literacy levels in which all students fell under performative levels of literacy (Purwanto 2008). Purwanto's (2008) study, however, indicated that 25 percent of the participants scored at the informative level on the speaking subtest and 20 percent scored at the informative level on the reading subtest while the current study indicates that 25 percent of the participants scored at the functional level on the speaking subtest and 20 percent scored at the functional level on the reading subtest. It is therefore recommended that action research be conducted in Central Java to upgrade the level of literacy from the performative level to the informative level of literacy. Special English instruction aimed at upgrading students' level of literacy to the informative level can be conducted through an action research project in which a teacher or lecturer may create an integrated teaching model for English and literacy and implement it in his or her class in Plan-Act-Observe-Reflect cycles. If the model proves effective, it can be used elsewhere to upgrade students' level of literacy. The results of such action research can be generalized for use at some other higher education settings with students of similar literary levels. Because the current study is a preliminary investigation, other studies need to be conducted for verification or falsification. Beyond action research projects, research investigating whether IELTS band scores are positively correlated with a particular level of literacy and employing a multi-discipline approach, especially with respect to the testing of literacy levels, would be informative.

\section{References}

Brydon, Diana. 2010. "Critical Literacies for Globalizing Times.” Critical Literacy: Theories and Practices 4 (2): 16-28.

Celce-Murcia, Marianne, Zoltan Dornyei, and Sarah Thurrell. 1995. “Communicative Competence: A Pedagogically, Moti- 
vated Model with Content Specifications.” Applied Linguistics 6 (2): 5-35

Department of National Education [Departemen Pendidikan Nasional]. 2006. RPP dan Silabus Bahasa Inggris [English Lesson Plan and Syllabus]. Jakarta: Department of National Education. Available online at: http://ktsp.files.wordpress.com.

Freebody, Peter, and Allan Luke. 1990. "Literacy Programs: Debate and Demands in Cultural Contexts.” Prospect 5 (3): 7-16.

Grant, Audrey. 1986. "Defining Literacy: Common Myths and Alternative Readings.” Australian Review of Applied Linguistics 9 (2): 1-22.

Griffith University. 2012. Admission Requirements. Master of Arts in Applied Linguistics/TESOL. Language Requirements. Brisbane, Australia: Griffith University. Available online at: http://www148.griffith.edu.au/programs-courses.

Hammond, Jennifer, Anne Burns, Helen Joyce, Daphne Brosnan, and Linda Gerot. 1992. English for Social Purposes: A Handbook for Teachers of Adult Literacy. Australia: Macquarie University.
Holme, Randal. 2004. Literacy: An Introduction. Edinburgh: Edinburgh University Press.

Jakeman, Vanessa, and Claire Mcdowell. 2002. IELTS Practice Test Plus. Essex: Pearson Education Limited.

Purwanto, Sugeng. 2007. A Critical Discourse Analysis of the Author's Rhetorical Strategies to Reveal the Struggle of Ideology in Richard Mann's "Plots and Schemes that Brought down Soeharto.” Unpublished PhD diss., Universitas Negri Semarang (UNNES), Semarang, Indonesia.

Purwanto, Sugeng. 2008. “An Analysis of IELTS-Based Literacy Levels: A Case Study at the First Semester Students of FBIB Unisbank, Semarang." Dinamika Bahasa dan Budaya [Dynamics of Language and Culture] 2 (2): 1-12.

UNESCO. 2009. "2009 World Conference on Higher Education: The New Dynamics of Higher Education and Research for Societal Change and Development." Communique of WCHE 2009 Conference, Paris 5-8 July 2009.

Wells, Gordon. 1987. “Apprenticeship in Literacy.” Interchange 18 (1/2): 109-123. 